\title{
Estimation of the Carbon Biomass Stored in the Forest Ecosystem of the Billings Reservoir-SP
}

\author{
Cleber Vinicius Vitorio da Silva ${ }^{\text {; }}$ Luiz Alberto Santos Abreu ${ }^{2}$; Karina Arruda da Silva ${ }^{3}$; Elenice \\ Rachid da Silva Lenz ${ }^{4}$; Josimar Ribeiro de Almeida ${ }^{2}$
}

凶lebervitorio88@gmail.com

\author{
1. Universidade Estácio de Sá 2. Universidade do Estado do Rio de Janeiro 3. Universidade de Americana 4. \\ Universidade Federal do Rio de Janeiro
}

Histórico do Artigo:

Recebido em: 24 de outubro de 2018

Aceito em: 14 de maio de 2019

Publicado em: 30 de agosto de 2019

\begin{abstract}
Global warming has become international concern, culminating with the ratification of the Kyoto Protocol which includes definitions and objectives of the sustainable development mechanisms and features that make it easier for the industrialized countries to jointly compensate for their polluting greenhouse gas emissions. São Paulo is a state known for its industrial development and distortion of the green areas in ecosystems associated with the Atlantic Forest biome. In the middle of this chaotic scenery lies the Billings reservoir in São Bernardo do Campo-SP, its forest ecosystem is the provider of numerous environmental services. Quantification of biomass (Bwood) of stems resulted in estimates of 113.73.ha-l, which corresponded to 56.87 tC.ha-l. The estimates obtained for the forest ecosystem of the reservoir can be used as a reference for the establishment of forest restoration projects under the under the sustainable development mechanism established the Kyoto Protocol.
\end{abstract}

Keywords: Environmental service, Atlantic forest, forest inventory, dendrometry.

\section{Estimativa da Biomassa de Carbono Armazenada no Ecossistema Florestal do Reservatório Billings - SP}

Resumo: 0 aquecimento global tornou-se preocupação internacional, culminando com a ratificação do Protocolo de Quioto, onde constam as definições e os objetivos dos mecanismos de desenvolvimento sustentável e possui procedimentos flexibilizadores, facilitando aos paises industrializados compensar em conjunto suas emissões poluentes de gases do efeito estufa. São Paulo é um estado conhecido pelo desenvolvimento industrial e descaracterização das áreas verdes dos ecossistemas associados ao bioma Mata Atlântica. Frente a este cenário caótico está à represa Billings em São Bernardo do Campo-SP, seu ecossistema florestal é prestador de uma série de serviços ambientais. A quantificação da biomassa (Bmadeira) do fuste resultou em estimativas de 113,73 t.ha-1, o que correspondeu a 56,87 tC.ha-1. As estimativas obtidas para o ecossistema florestal da represa podem ser usadas como referência para o estabelecimento de projetos de restauração florestal, no âmbito do mecanismo de desenvolvimento sustentável, estabelecido no Protocolo de Quioto.

Palavras-chave: Serviço Ambiental, Mata Atlântica, inventário Florestal, dendrometria. 


\section{Estimación de La Biomasa de Carbono Almacenada en el Ecosistema Forestal del Embalse de Billings-SP}

Resumen: El calentamiento global se ha convertido en preocupación internacional, culminando con la ratificación del Protocolo de Kioto, donde constan las definiciones y los objetivos de los mecanismos de desarrollo sostenible y tiene procedimientos flexibilizadores, facilitando a los países industrializados compensar conjuntamente sus emisiones contaminantes de gases de efecto invernadero. São Paulo es un estado conocido por el desarrollo industrial y descaracterización de las áreas verdes de los ecosistemas asociados al bioma Mata Atlántica. Frente a este escenario caótico está a la represa Billings en São Bernardo do Campo-SP, su ecosistema forestal es prestador de una serie de servicios ambientales. La cuantificación de labiomasa (Bmadeira) del fuste resultó en estimaciones de 113,73 t.ha-1, lo que correspondió a 56,87 tC.ha-l. Las estimaciones obtenidas para el ecosistema forestal de la represa pueden ser usadas como referencia para el establecimiento de proyectos de restauración forestal, en el marco del mecanismo de desarrollo sostenible, establecido en el Protocolo de Kioto.

Palabras clave: Servicio Ambiental, Mata Atlántica, inventario Forestal, dendrometría.

\section{INTRODUÇ̃̃o}

Approximately 54.4\% of Brazil's territory is occupied by forests (FLORESTAS D0 BRASIL, 2015 ) and from this percentage, approximately $12.5 \%$ corresponds to the area of the Atlantic Rainforest Biome (SOS MATA ATLÂNTICA, 2015), stretching for 17 States of the federation, going from the state of Rio Grande do Sul to Rio Grande do Norte, ranging from the coastal regions, such as plateaus and hills of the interior.

In the state of São Paulo, the Atlantic Forest biome offers characteristic phytoecological formations constituted by forest ecosystems: Seasonal Semidecicual Forest and Dense Ombrophilous Forest. The latter features subdivisions in its phytophysiognomy, suffering variations according to the altitude range of relief where it is inserted. The divisions are: The Alluvial Lowlands, Submontane Forest, Montana and Alto-Montana (SOS MATA ATLÂNTICA, 2015).

According to RODRIGUES et al., (2017), in addition to this important set of forest ecosystems, the Atlantic Forest also covers other associated ecosystems such as mangroves, restingas, mixed Araucarias forestry and the altitude fields.

The biome stretched by more than $90 \%$ of the total area of the state of São Paulo, according to the annual balance sheet presented by the non-governmental organization SOS MATA ATLÂNTICA (2015), until the end of the 1990's, approximately 15\% of the area of this territory was still covered by native vegetation. The report of the institution demonstrates that the historical process of anthropic intervention has been happening since the discovery 
of Brazil and has been expanding over the centuries, due to some activities of economic development, such as exploitation of timber, agricultural and industrial activities. Another factor associated with the loss of vegetation is the unplanned urban growth, which in Brazil occurs mainly in areas that are covered by the biome (SOS Mata Atlântica, 2015).

According to INPE (2018), of the total Atlantic Forest, 23,548 hectar of vegetation were suppressed of which corresponds to $7 \%$ of its forest remains, safeguarded mainly in this areas of more difficult access, how to slopes of the Serra do Mar, considered unsuitable for agricultural practices. This territory has large forest spots adjacent to areas of high fragmentation (ARROMBA et al., 2012). The law $\mathrm{N}^{0} 11.428 / 2006$ determines the area of protection of the biome for the 17 states of the federation, which corresponds to $38 \%$ of the Brazilian territory. Studies of the INPE (2018) point out that the whole area of Atlantic Forest had approximately $1,300,000 \mathrm{~km}^{2}$ of extension, and now is reduced to $162,666 \mathrm{~km}^{2}$, the equivalent to $12.4 \%$ of its original forest cover, as today has many uses, some of them being: the remaining forest, planted forests (mainly pinus and eucalyptus), pastures and agricultural crops of annual and perennial plants.

However, even facing an intense and historical process of deforestation, the Atlantic Forest biome has one of the largest biodiversity in the planet, with high concentrations of endemic species (BERGALL0 et al., 2016) and a high level of degradation. Thus, it is possible to consider it as a hotspot, being the conservation of its natural resources of utmost importance to mankind.

The plants are autotrophicorganisms, they need of CO2 for the production of their food through the photosynthetic process, in woody plants the incorporation of a part of this carbon in the secondary xylem of plant is popularly known as wood (SILVA et al., 2017). There are methods that allow researchers to evaluate the concentration of carbon in woody plants, however in native forests these measurements are only estimated, for in a community there is not a single model of growth and morphotype, because it is a set of populations dependent on the ecological relationships (HENRY et al., 2011).

Carbon sequestration and storage is, among the many environmental services provided by forests, one of great importance. Especially in face of global warming's intensification (SILVA et al., 2017). The phenomenon mentioned above is cause by the increase of the concentration of greenhouse gases, especially carbon dioxide (CO2), methane (CH4) and nitrous oxide (N20), from human emissions (SILVA et al., 2017). 
In order to mitigate these impacts arising from the emission of greenhouse gases, the Kyoto Protocolwas created, as countries held as their paramountgoal the reduction of emissions of these gases in 5.0\% during the period from 2008 to 2012, which corresponds to the first commitment period. The Protocol officially came into effect in February 2005 and brought three innovative mechanisms to ensure flexibility: Emissions trading, Joint Implementation and Clean Development Mechanism (CDM), by which it is possible to obtain the Certified Emission Reductions (CERS), which are one of the types of carbon credits. It is noteworthy that among these three mechanisms of flexibilization, only the CDM allows the participation of developing countries like Brazil, representing, therefore, a way for the country's participation in the recent and innovative carbon credits market (TORRES et al., 2013).

The state of São Paulo is included in the Atlantic Forest domain. The devastation of forests in this state is happening almost since the period of its discovery, drastically reducing their original vegetation coverage. Only $7.26 \%$ of the original area remains (TAVARES et al, 2012; FUNDAÇÃO SOS MATA ATLÂNTICA et al., 2011), it is vital that the green areas and woody species that still exist are preserved. Especially considering the various services that the forest ecosystem can provide., such as: maintenance of water resources, conservation and preservation of soils and the concentration of atmospheric carbon in forest fragments.

The city São Bernardo do Campo is located at the top of the Serra do Mar, the Atlantic Plateau, however in almost every area of Atlantic Forest in the region, it is possible to observe influxes of eucalyptus and pine trees, the livestock and agriculture also distort the Atlantic Forest site, in addition to the massive synthesis of real estate ventures.

Billings reservoir is one of the biggest and most important reservoirs of water in the Metropolitan Region of São Paulo. The West borders the watershed of the Guarapiranga reservoir, and South, Serra do mar. Its main rivers and streams are the Rio Grande or Jurubatuba. Located in a fishing region with an emerging spot of strong environmental interest, its area of the original forest is altered, when not completely deleted due to the deployment of real estate ventures or agriculture, in addition to the cultivation of Pinus sp., Eucalyptus sp. and Corymbia sp. For these reasons, even today, its humid areas of ecotone with rain forests and gallery forests, although quite affected by human activity, stand still as important floristic and faunistic elements of interest to conservationists, especially the flora (SOS MATA ATLÂNTICA, 2015).

Because of importance of the Billings reservoir for the state of São Paulo and the need for the preservation of its ecosystem, the objective of this work was to quantify biomass in m3 
through the installation of 54 plots (UA) of $36 \mathrm{~m} 2$ arranged systematically in a forest fragment of 48,010.91 m2 encompassing a sampling area of $1944 \mathrm{~m} 2$, with the purpose of estimating the concentration of carbon in $\mathrm{tC} \cdot \mathrm{ha}-1$ which is concentrated by the forest ecosystem of the dam.

\section{MATERIAL E MÉTODOS}

\section{Characterization of the study área}

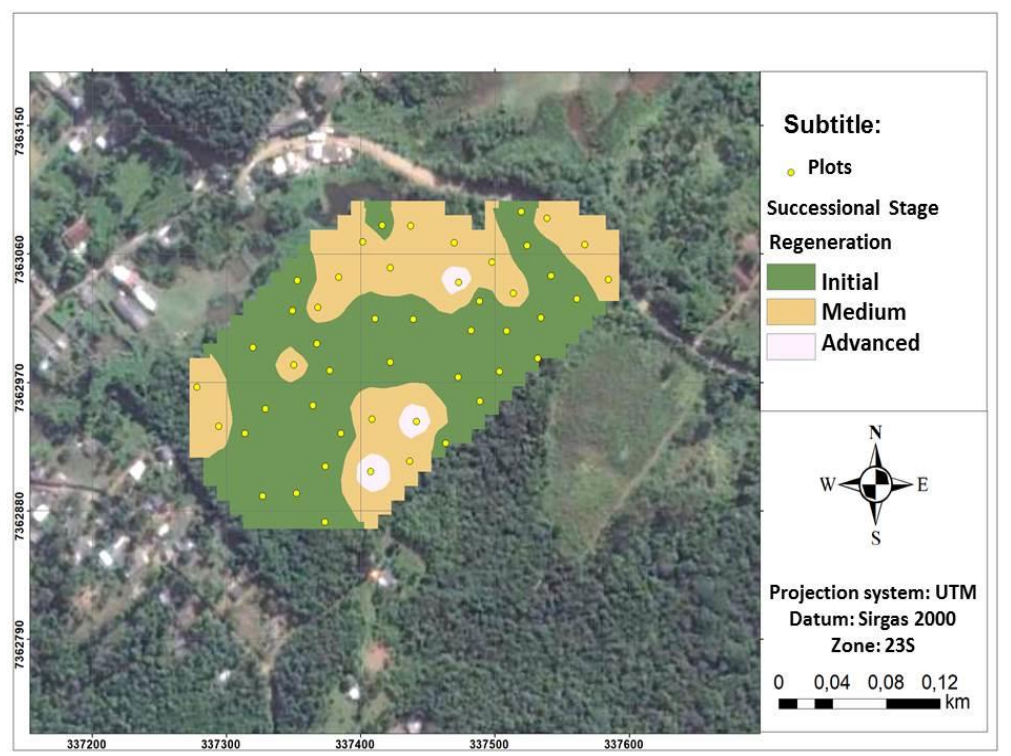

Figure 1 - Classification of successional stage of regeneration of the fragment and provision of sample units in the area of studies. Total area: $48,010.91 \mathrm{~m}^{2}$.

Source: by the author himself.

The forest fragment is located in the area of influence of the Billings reservoir (Figure 1) in the municipality of São Bernardo do Campo, which is one of the largest and most important reservoirs of water in the Metropolitan Region of São Paulo.

The dam was conceived in the decades of 1930 and 1940 by engineer Billings, one of the employees of the formerenergy provider Light. Initially, the dam had the objective of storing water to generate electrical power for the hydroelectric plant Henry Borden in Cubatão.

The city São Bernardo do Campo has a warm climate and temperate climate. There is significant rainfall throughout the year, even the driest month there is plenty of rainfall. According to the Köppen Geiger and the climate is classified as Cfb (LUCHIARI et al., 2012). In São Bernardo do Campo, the average temperature is $17.8^{\circ} \mathrm{C}$, the average annual rainfall is 1524 $\mathrm{mm}$. The difference between the precipitation of the driest month and the rainiest is $190 \mathrm{~mm}$. Throughout the year the average temperatures vary $6.5^{\circ} \mathrm{C}$. The hottest month of the year is 
February with an average temperature of $20.9^{\circ} \mathrm{C}$. July has an average temperature of $14.4^{\circ} \mathrm{C}$, this was the lowest mean temperature, precipitation in the month of July is $44 \mathrm{~mm}$, this being the driest month. The wettest month was January, with an average of $234 \mathrm{~mm}$.

The forest fragment located in the Taquacetuba Road, in the Taquacetuba neighborhood, under the inscription 624700708000, in the Alto-Tietê's basin area, specifically in the sub-basin of the Billings reservoir. The main access roads to the location of the project are by the highway of Imigrantes and by Mário Covas Beltway, so it is in an important and privileged geographical position. In accordance with the environmental process N 59.602/2017, the fragment has 3 stages of succession: initial, medium and advanced, the largest portion of the successional stage corresponding to the 'initial' stage.

\section{Sample Design and Analysis}

From 10 December until 23 December 2017, 54 quadratic sampling units (6x6 m) were demarcated in the area of the venture, totaling $1944 \mathrm{~m} 2$ of sample area (Figure 1) the fragment studied has a total area of 48,010.91 $\mathrm{m} 2$, the field team catalogued all the botanical species existing in the quadratic plots of $36 \mathrm{~m} 2$, theymade these plots with tape and string. Within each quadratic plot they were collected arboreal species with CAP greater than or equal to 5 $\mathrm{cm}$, and estimated the height and the radius of the canopy of sampled individuals. The quadrats were marked with striped tape. The vertex closest to the access to the sampling unit was georeferenced using a GPS with an accuracy of 3 meters under vegetation cover. The individuals were collected and catalogued in the herbarium of the laboratory of forage plants of UFRJ at the Instituto de Zootecnia and stored at the Laboratory of Environmental Mapping of UFRRJ (LAMAGEDENASA).

The simple random sampling is the fundamental process of selection from which to derive all other sampling procedures, aiming to increase the accuracy of estimates and to reduce the costs of the survey (RIBEIR0 et al., 2009).

The simple random sampling is the best method for presentation of the theory of sampling, because it allows estimating the sampling error. The selection of each sampling unit must be free of any choice and totally independent from the selection of the other sample units. The equation for the calculation of the sample sufficiency in simple random sampling is shown below (HUSCH et al.1982) (Equation 1):

$$
\mathrm{n}=\mathrm{N} \times \mathrm{S}^{2} \times \mathrm{t}^{2} /\left(\mathrm{N} \times\left(\mathrm{E} \times \mathrm{x}^{-}\right)^{2}+\mathrm{S}^{2} \times \mathrm{t}^{2}(\mathrm{l})\right.
$$


Where:

$\mathbf{n}=$ number of parcels to be raised;

$\mathrm{N}=$ total number of samples possible in the area;

$\mathrm{t}=$ value of probability distribution $\left(\mathrm{t}_{0.10}\right.$, with $\left.\mathrm{n}-1 \mathrm{GL}\right)$;

$S^{2}=$ variance of the parameter evaluated;

$\mathbf{x}^{-}=$average

$\mathrm{E}=$ Error $(10 \%)$ and $\mathrm{X}=$ Average of the parameter evaluated.

The following are defined the symbols to identify the variables of the Community:

The sample sufficiency was calculated on the basis of the parameter number of adult individuals, in view of the interest of the evaluation of the quantification of biomass in $\mathrm{m}^{3}$ and quantification of carbon stored in the tC.ha- ${ }^{-1}$ of plants with CAP above or equal to $5 \mathrm{~cm}$.

For the analysis of total biomass by species and botanical family we used the volumetric equation of CETEC (1995) which is used by other authors (RIBEIR0 et al., 2009), Atlantic Forest vegetation (equation 2):

$$
\mathrm{Vt}=0.00007423 \times \mathrm{DAP}^{1.707348} \times \mathrm{Ht}^{1.16873}
$$

Where:

$\mathrm{Vt}=$ total volume of the bole;

$\mathrm{DAP}=1.30 \mathrm{~m}$ above the ground;

$\mathrm{Ht}=$ total height of each stem.

The estimate of the bole biomass was performed using the non-destructive method, depending on the impossibility of using the destructive method, due to restrictions of legal orders and operational. Thus, it was evaluated only the biomass of the stem and not other forest compartments, such as branches, leaves, bark and lianas.

The indirect method for quantification of biomass is based on the use of empirical relationships between biomass and other variables in the tree (DBH, total height etc.) (CETEC, 1995), these relations expressed by means of statistical models (SILVA et al., 2017). One needs to be cautious with its implementation, in order to avoid significant error in the calculation of biomass: a careful analysis of the situations of field (ex. hollow trees) and the sample is representative of the area (SILVA et al., 2013). 
This method is often considered a more accurate alternative than the direct method, since in the latter, the information obtained usually come from parcels of small size, in a small number and selected intentionally, usually in areas that are more representative of the whole (BROWN et al., 1989). Such conduct could introduce errors of biased estimates, which may lead to over- or underestimation of the average biomass of the forest evaluated.

Considering the use of non-destructive method, we performed the selection of species with secondary xylem in the area (CETEC, 1995). Then, we obtained the values of basic density for each lignified species selected, based on existing studies (LORENZI, 2014; IBAMA, 2014). To determine the basic density of species not identified (Indet), we collected bodies of evidence, using a Pressler probe. The collections were always carried out in the morning, in order to avoid possible variations of the values of which could be caused by changes in water potential and perspiration after noon and the samples were stored individually in a plastic bag sealed until laboratory measurements. Synthesized the methodology for determining the basic density of the wood in the lab, as it is instructed in the norm ABNT NBR 11941 NBR11941, as for deceased individuals, we used an average value of the bodies of evidence sampled.

The basic density values obtained, already converted into Ton.m ${ }^{-3}$, it was calculated the average basic density ( $\mathrm{d}$ ) of all the mature forest, weighted by the value of coverage, according to Equation 3:

$$
\mathrm{d}=\sum_{\mathrm{i}=\mathrm{l}}^{\mathrm{n}} \llbracket\left(\mathrm{Db}_{\mathrm{i}} \times\left(\frac{\mathrm{VC}_{\mathrm{i}}}{\sum_{\mathrm{i}-=1}^{\mathrm{n}} \mathrm{VC}_{\mathrm{i}}}\right)\right)(3)
$$

Where:

n = number of selected species;

Dbi = basic density of the ith species selected, in Ton.m ${ }^{-3}$; and

$\mathrm{VCi}$ = average value of coverage of the $\mathrm{i}$-th species with secondary xylem.

The biomass of wood present in the stem of each tree was estimated by multiplying the average wood basic density by volumes of the stems (equation 2), according to Equation 4 :

$$
B_{\text {wood }}=d \times x^{-} \times V t(4)
$$

Where:

B = biomass of the stem, in Ton;

$\mathbf{d}=$ average basic density of the wood, in Ton.m ${ }^{-3}$; and

$\mathrm{Vt}=$ total volume estimated de Stem, in $\mathrm{m}^{3}$. 
The carbon stored in the bole biomass was estimated by means of the multiplication of the estimates of biomass obtained by factor 0.5 , considering that the dry biomass contains approximately 50\% of carbon (RIBEIR0 et al., 2009). Then, the stock of carbon was extrapolated to tons per hectare.

\section{RESULTADOS E DISCUSSÃ0}

Were measured in 553 trees (622 stems), distributed in 26 families, 49 taxa identified up to species or genus, and only 5 could not be identified because of the impossibility of collection by the height and density of the canopy. Of this total, fifty-four (54) individuals were dead. For the calculation of the sample sufficiency in simple random sampling, met a $\mathrm{n}=$ 45.65 sample units ( $\mathrm{U}$ A) for the total area of 48,010.91 $\mathrm{m}^{2}\left(\mathrm{~N}=54 ; \mathrm{S}^{2}=24.40531 ; \mathrm{S}=4.94\right.$ plants; Std. Error= 0.67 plants; $\mathrm{CV}=42.89 \%$; an estimate of the total population= 57.613092; $\mathrm{CI}=12 \pm 1.12$ plants per hectare), so the allocation of 54 plots of $36 \mathrm{~m}^{2}$ was sampled more than representative for this work, it can be concluded that the sampling was sufficient.

Table 1 - List of species sampled in the sample units.

\begin{tabular}{|c|c|c|c|c|c|c|c|}
\hline $\mathrm{N}$ & Family & Species & Ind. & Stems & $\mathrm{G}\left(\mathrm{m}^{2}\right)$ & $\begin{array}{c}\text { Height } \\
\text { x-bar } \\
\text { (m) }\end{array}$ & $\begin{array}{l}\text { Qnt. } \\
\text { Plot }\end{array}$ \\
\hline 1 & Euphorbiaceae & Alchornea sp. & 12 & 13 & 0.053991 & 9.38 & 8 \\
\hline 2 & Euphorbiaceae & $\begin{array}{l}\text { Alchornea triplinervia (Spreng.) } \\
\text { Müll.Arg. }\end{array}$ & 6 & 6 & 0.030035 & 7.5 & 5 \\
\hline 3 & Annonaceae & Annona sp. & 1 & 1 & 0.001912 & 5 & 1 \\
\hline 4 & Asteraceae & Baccharis oreophila Malme & 10 & 10 & 0.042693 & 5.25 & 6 \\
\hline 5 & Meliaceae & Cabralea canjerana (Vell.) Mart & 1 & 1 & 0.002037 & 5 & 1 \\
\hline 6 & Salicaceae. & Casearia sylvestris Sw. & 9 & 10 & 0.046483 & 6.1 & 7 \\
\hline 7 & Urticaeae & Cecropia glaziovii Snethl. & 1 & 1 & 0.019107 & 11 & 1 \\
\hline 8 & Clethraceae & Clethra scabra Pers. & 43 & 49 & 0.396869 & 7.47 & 22 \\
\hline 9 & Clusiaceae & Clusia criuva Cambess. & 24 & 35 & 0.177858 & 6.81 & 12 \\
\hline 10 & Polygonaceae. & Coccoloba glaziovii Lindau & 7 & 7 & 0.064569 & 7 & 4 \\
\hline 11 & Sapindaceae & Cupania oblongifolia Mart. & 3 & 8 & 0.031284 & 7.31 & 3 \\
\hline 12 & Cyatheaceae & $\begin{array}{l}\text { Cyathea cf. Corcovadensis } \\
\text { (Raddi) Domin }\end{array}$ & 21 & 21 & 0.102577 & 15.49 & 8 \\
\hline 13 & Myrtaceae & Eucaliptussp & 2 & 2 & 0.209551 & 19 & 1 \\
\hline 14 & Myrtaceae & Eugenia glazioviana Kiaerskcf & 1 & 3 & 0.006802 & 8 & 1 \\
\hline 15 & Myrtaceae & Eugenia pruniformis Cambess. & 1 & 1 & 0.012104 & 11 & 1 \\
\hline 16 & Myrtaceae & Eugenia uniflora L. & 1 & 2 & 0.065969 & 8.5 & 1 \\
\hline 17 & Arecaceae & Euterpe edulis Mart & 9 & 9 & 0.032119 & 3.43 & 5 \\
\hline
\end{tabular}




\begin{tabular}{|c|c|c|c|c|c|c|}
\hline 18 & Rubiaceae & Faramea tetragona Müll.Arg. & 6 & 6 & 0.020873 & 6.75 \\
\hline 19 & Moraceae & Ficus elastica Roxb. & 2 & 2 & 0.011539 & 6.25 \\
\hline 20 & Asteraceae & $\begin{array}{l}\text { Gochnatia polymorpha (Less.) } \\
\text { Cabrera }\end{array}$ & 2 & 3 & 0.175604 & 11.5 \\
\hline 21 & Nyctaginaceae & Guapira opposita (Vell.) Reitz & 3 & 3 & 0.043418 & 6.67 \\
\hline 22 & Meliaceae & Guarea macrophylla Vahl & 3 & 3 & 0.01052 & 6.17 \\
\hline 23 & Annonaceae & Guatteria australis A.St.-Hil & 6 & 6 & 0.01656 & 5.84 \\
\hline 24 & & 1 Indet & 1 & 1 & 0.013377 & 11 \\
\hline 25 & & 2 Indet & 1 & 1 & 0.019894 & 7 \\
\hline 26 & & 3 Indet & 1 & 1 & 0.004584 & 7 \\
\hline 27 & & 4 Indet & 1 & 2 & 0.044699 & 9.5 \\
\hline 28 & & 5 Indet & 1 & 1 & 0.016114 & 10 \\
\hline 29 & Bignoniaceae & Jacaranda puberula Cham & 2 & 3 & 0.00193 & 6.67 \\
\hline 30 & Lauraceae. & Endlicheria sp. & 2 & 2 & 0.010968 & 7.25 \\
\hline 31 & Sapindaceae & Matayba intermedia Radlk & 4 & 8 & 0.233703 & 13.69 \\
\hline 32 & Celastraceae & Maytenus sp. & 1 & 1 & 0.020698 & 10 \\
\hline 33 & Melastomataceae & $\begin{array}{l}\text { Miconia cinnamomifolia (DC.) } \\
\text { Naudin }\end{array}$ & 26 & 30 & 0.121853 & 4.95 \\
\hline 34 & Melastomataceae & Miconia cubatanensis Hoehne & 8 & 8 & 0.098415 & 8.44 \\
\hline 35 & Melastomataceae & Miconia fasciculata Gardner & 19 & 23 & 0.076209 & 5.05 \\
\hline 36 & Melastomataceae & Miconi asp. & 1 & 1 & 0.014037 & 8 \\
\hline 37 & & Dead & 54 & 60 & 0.389364 & 4.55 \\
\hline 38 & Myrtaceae & Myrcia multiflora (Lam.) DC. & 1 & 1 & 0.003026 & 7.5 \\
\hline 39 & Myrtaceae & Myrcia sp. & 1 & 1 & 0.014714 & 8 \\
\hline 40 & Myrtaceae & Myrcia sp2. & 1 & 1 & 0.0023 & 6.5 \\
\hline 41 & Myrtaceae & Myrcia splendens (Sw). DC & 21 & 22 & 0.012252 & 6.38 \\
\hline 42 & Myrsinaceae & $\begin{array}{l}\text { Myrsine aff. Balansae Mez } \\
\text { Otegui }\end{array}$ & 21 & 22 & 0.101511 & 6.42 \\
\hline 43 & Myrsinaceae & $\begin{array}{l}\text { Myrsine coriácea }(\mathrm{Sw}) \text {. R.Br. Ex } \\
\text { Roem. \& Schult }\end{array}$ & 6 & 7 & 0.04442 & 6.64 \\
\hline 44 & Myrsinaceae & Myrsine gardneriana A.DC. & 2 & 2 & 0.02038 & 8.5 \\
\hline 45 & Lauraceae. & Nectandra grandiflora Nees & 3 & 3 & 0.01582 & 5.77 \\
\hline 46 & Lauraceae. & Nectandra sp. & 2 & 2 & 0.012323 & 6.5 \\
\hline 47 & Lauraceae. & Nectandra sp2. & 1 & 1 & 0.004584 & 7 \\
\hline 48 & Lauraceae. & $\begin{array}{l}\text { Ocotea aff. nitida (Meisn.) } \\
\text { Rohwer }\end{array}$ & 1 & 1 & 0.004029 & 8 \\
\hline 49 & Lauraceae. & Ocotea odorifera (Vell.) Rohwer & 3 & 3 & 0.009995 & 6.67 \\
\hline 50 & Peraceae & $\begin{array}{l}\text { Pera glabrata (Schott) Poepp. } \\
\text { Ex Baill. }\end{array}$ & 2 & 2 & 0.004615 & 6 \\
\hline 51 & Pinaceae. & Pinus sp. & 5 & 5 & 0.422914 & 14.8 \\
\hline 52 & Asteraceae & $\begin{array}{l}\text { Piptocarpha axillaris (Less.) } \\
\text { Baker }\end{array}$ & 6 & 6 & 0.086509 & 7.67 \\
\hline 53 & Asteraceae & Piptocarpha sp. & 1 & 1 & 0.004974 & 8 \\
\hline 54 & Myrtaceae & Psidium cattleianum Sabine & 8 & 10 & 0.038149 & 6.15 \\
\hline 55 & Myrtaceae & Psidium sp. & 10 & 10 & 0.026889 & 4.5 \\
\hline 56 & Rubiaceae & Psychotria sp. & 1 & 1 & 0.00179 & 5 \\
\hline 57 & Rubiaceae & Psychotria suterella Mull. Arg. & 1 & 1 & 0.002037 & 3 \\
\hline 58 & Rubiaceae & Psychotria vellosiana Benth. & 2 & 2 & 0.006724 & 5.5 \\
\hline 59 & Rubiaceae & Bathysa gymnocarpa K. Schum. & 2 & 2 & 0.008157 & 6 \\
\hline
\end{tabular}




\begin{tabular}{|c|c|c|c|c|c|c|c|}
\hline 60 & Euphorbiaceae & $\begin{array}{l}\text { Sapium glandulosum }(\mathrm{L} .) \\
\text { Morong }\end{array}$ & 4 & 4 & 0.00992 & 11.13 & 4 \\
\hline 61 & Anacardiaceae. & Schinus terebinthifolia Raddi & 19 & 23 & 0.257813 & 6.79 & 12 \\
\hline 62 & Styracaceae & $\begin{array}{l}\text { Styrax lancifolius Klotzsch ex } \\
\text { Seub }\end{array}$ & 1 & 3 & 0.015231 & 7 & 1 \\
\hline 63 & Arecaceae & $\begin{array}{l}\text { Syagrus Romanzoffiana (Cham.) } \\
\text { Glassman }\end{array}$ & 6 & 6 & 0.147465 & 7.75 & 6 \\
\hline 64 & Melastomataceae & $\begin{array}{l}\text { Tibouchina mutabilis (Vell.) } \\
\text { Cogn. }\end{array}$ & 118 & 128 & 1.632466 & 7.43 & 38 \\
\hline 65 & Sapindaceae & Toulicia Laevigatara dlk & 4 & 4 & 0.008165 & 6.38 & 3 \\
\hline 66 & Cannabaceae & Trema micrantha (L.) Blume & 1 & 1 & 0.020698 & 13 & 1 \\
\hline 67 & Rutaceae & Zanthoxylum fagara (L.) Sarg & 2 & 2 & 0.077811 & 10.5 & 2 \\
\hline \multirow[t]{2}{*}{68} & Rutaceae & Zanthoxylum rhoifolium Lam. & 1 & 1 & 0.002578 & 6.5 & 1 \\
\hline & & Total & 553 & 622 & 5.660578 & 7.74 & 315 \\
\hline
\end{tabular}

The most representative family was Myrtaceae with 16.13\% of the 553 individuals in 54 sample units (Table 1), followed by Lauraceae with 9.68\% and Rubiaceae and Melastomataceae, both with $8 \%$, all these species representative of the environment of Atlantic Forest, however individuals in the family Fabaceae were not sampled within the 54 sample units.

The rate of bifurcation of the community forestry analyzed was $12.48 \%$, while the bifurcation may be associated with adverse environmental impacts as the insolation and damage the structure of trees (SILVA et al., 2013; SANTOS \& VALCARCEL, 2011), the bifurcation can also be associated with sunshine and fires, however, the species that contributed most to the rate of bifurcation was Clusia criuva Cambess., which has naturally high rates of bifurcation, a characteristic auto-ecological of the representatives of the family Clusiaceae. From the diametric structure drafted, it was found that the community forestry (Figure 2) showed a tendency to a J-inverted, as, the higher number of individuals found in the smallest diameter classes, which is a typical behavior of multianeforests (SILVA et al., 2017).

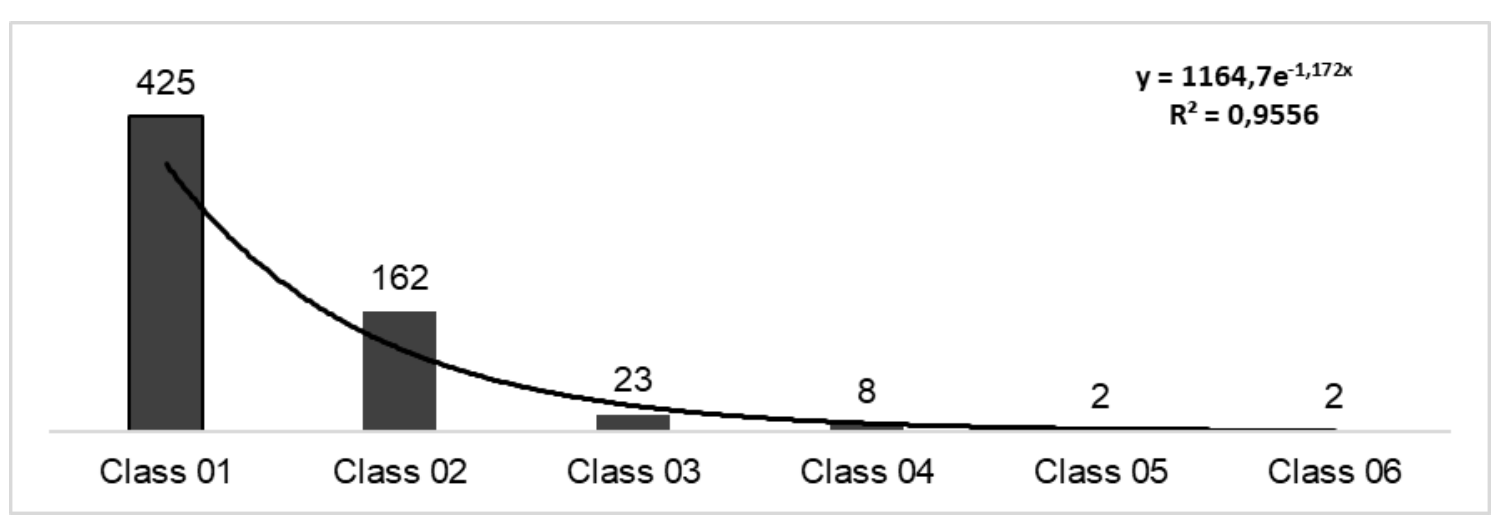

Figure 2 - Distribution of frequency per class of Dbh of trees measured Source: by the author himself. 
The heights of the trees measured in the inventory were distributed in three (3) classes with amplitude of stratum: lower, middle and upper. Distributed in accordance with Resolution $N^{0} 1 / 1994$ of the Environment National Council (CONAMA), in which the lower strata concentrated trees with up to $5.2 \mathrm{~m}$, the middle stratum of trees that had the height exceeding $5.2 \mathrm{~m}$ until the height of $14.5 \mathrm{~m}$ and the upper stratum of trees with height greater than $14.5 \mathrm{~m}$. According to Martins, 1991, estimates of the heights of individuals shrubs and trees can provide important information for both the interpretation of vertical structure of the forest as an aid in understanding the dynamics of populations that compose it. According to the analysis of estimated heights of 553 trees (Figure 3), 202 are in the lower strata $(<5.2$ m), 393 are in the middle stratum ( $>5.2$ and $<14.5 \mathrm{~m}$ ) and 27 are located on the upper stratum (> $14.5 \mathrm{~m}$ ), indicating an environment of regeneration and with recruitment of new individuals in each stratum of the forest ecosystem.

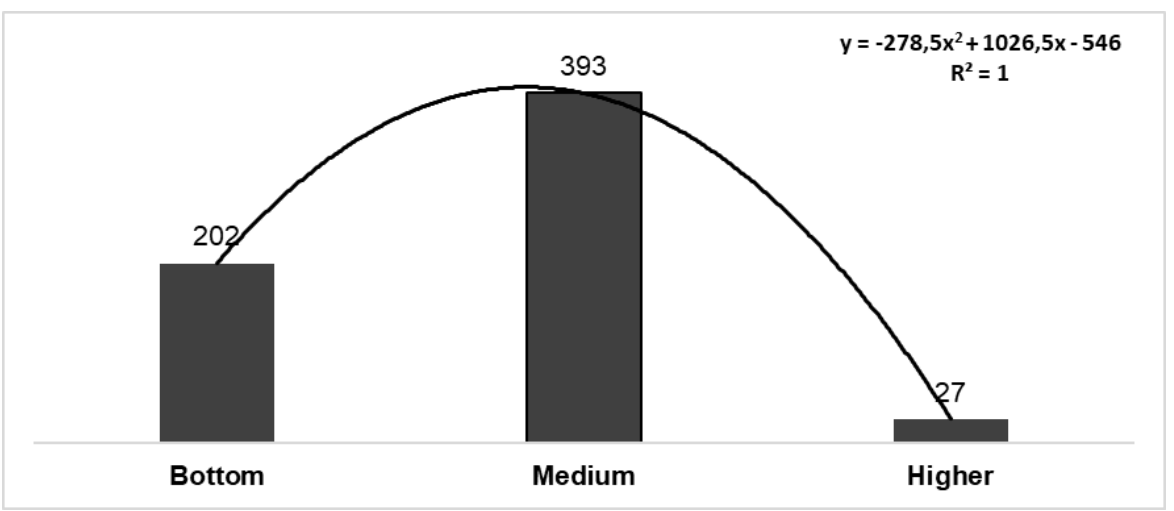

Figure 3 - The vertical structure of the forest ecosystem. Source: by the author himself.

For the analysis of biomass (VT), in $1944 \mathrm{~m}^{2}$ of Area Studies, we quantified $36.99 \mathrm{~m}^{3}$ of timber, so for each hectare of woody area of the Billings reservoir a quantification of $190.28 \mathrm{~m}^{3}$ is expected.

The families that have greater expression of biomass (Vt) in $\mathrm{m}^{3}$ (Figure 4) are: Melastomataceae $\left(10.71 \mathrm{~m}^{3}\right)$, Euphorbiaceae $\left(4.15 \mathrm{~m}^{3)}\right.$ and Myrtaceae $\left(3.91 \mathrm{~m}^{3}\right)$.

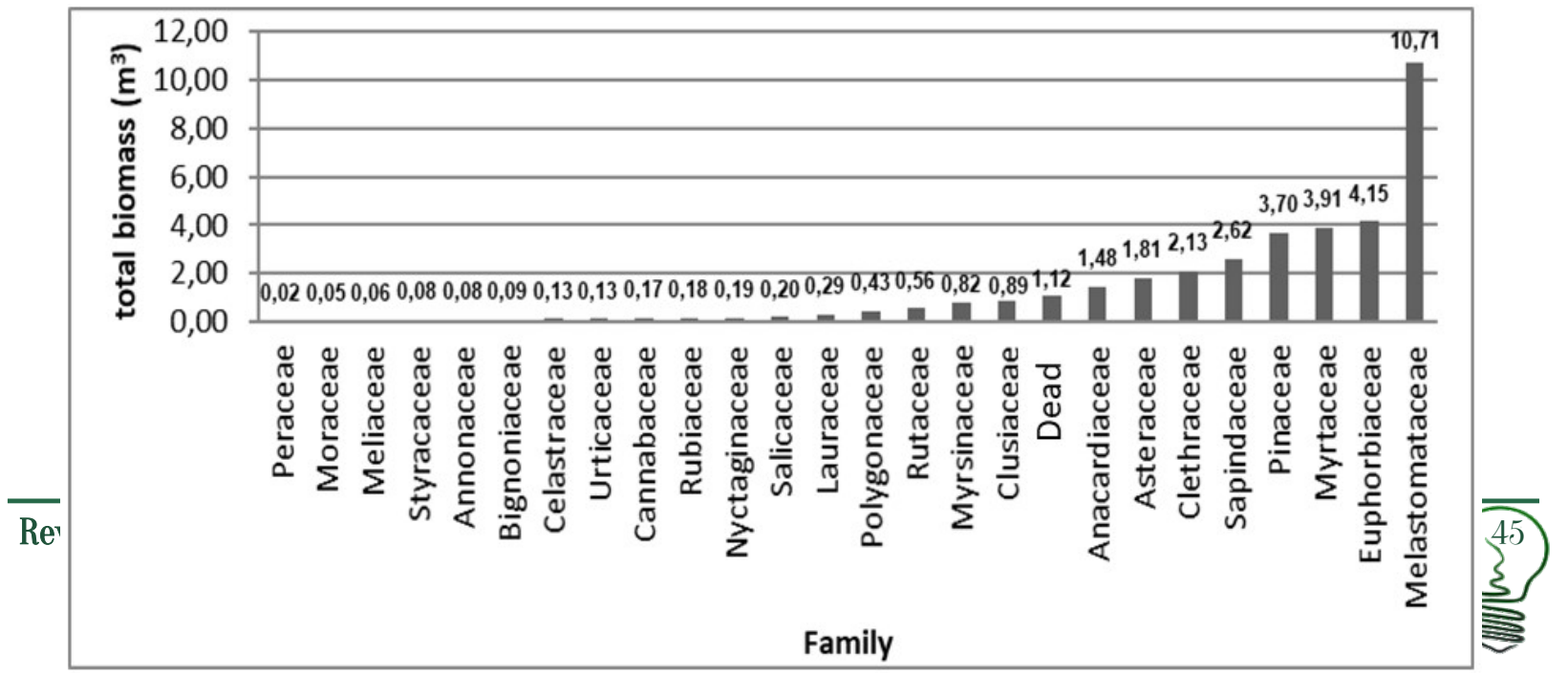


Figure 4 - Total biomass $\left(\mathrm{m}^{3}\right)$, by the botanical family sampled.

Source: by the author himself

Of the 69 species selected, the most representative in biomass $\left(\mathrm{m}^{3}\right)$ was Tibouchina mutabilis, which alone represents about $33 \%$ of biomass in the forest community analyzed.

Table 2 - Volume $\mathrm{m}^{3}$ per forest species sampled in community forestry.

\begin{tabular}{|c|c|c|c|c|c|}
\hline $\mathrm{N}$ & Species & Density ton $/ \mathrm{m}^{3}$ & $\mathrm{Vt}(\mathrm{CU})$ & $\operatorname{Dr}(\%)$ & $\mathrm{VC}$ \\
\hline 1 & Alchornea sp. & 0.44 & 3.19 & 2.17 & 1.562 \\
\hline 2 & $\begin{array}{c}\text { Alchornea triplinervia (Spreng.) } \\
\text { Müll.Arg. }\end{array}$ & 0.49 & 0.164 & 1.085 & 0.808 \\
\hline 3 & Annona sp. & 0.63 & 0.00743 & 0.181 & 0.107 \\
\hline 4 & Baccharis oreophila Malme & 0.45 & 0.17 & 1.808 & 1.281 \\
\hline 5 & Bathysa gymnocarpa K. Schum. & 0.64 & 0.035 & 0.362 & 0.253 \\
\hline 6 & Cabralea canjerana (Vell.) Mart & 0.69 & 0.00784 & 0.181 & 0.108 \\
\hline 7 & Casearia sylvestris Sw. & 0.84 & 0.204 & 1.627 & 1.224 \\
\hline 8 & Cecropia glaziovii Snethl. & 0.41 & 0.133 & 0.181 & 0.259 \\
\hline 9 & Clethra scabraPers. & 0.53 & 2.13 & 7.776 & 7.393 \\
\hline 10 & Clusia criuva Cambess. & 0.83 & 0.891 & 4.34 & 3.741 \\
\hline 11 & Coccoloba glaziovii Lindau & 0.89 & 0.434 & 1.266 & 1.203 \\
\hline 12 & Cupania oblongifolia Mart. & 0.67 & 0.175 & 0.542 & 0.548 \\
\hline 14 & Endlicheria sp. & 0.58 & 0.0612 & 0.362 & 0.278 \\
\hline 15 & Eucaliptus sp & 0.61 & 2.57 & 0.362 & 2.032 \\
\hline 16 & Eugenia glazioviana Kiaersk cf & 0.67 & 0.0451 & 0.181 & 0.15 \\
\hline 17 & Eugenia pruniformis Cambess. & 0.81 & 0.0902 & 0.181 & 0.197 \\
\hline 18 & Eugenia uniflora L. & 0.85 & 0.189 & 0.181 & 0.673 \\
\hline 20 & Faramea tetragona Müll.Arg. & 0.52 & 0.107 & 1.085 & 0.727 \\
\hline 21 & Ficus elastica Roxb. & 0.52 & 0.0493 & 0.362 & 0.283 \\
\hline 22 & $\begin{array}{l}\text { Gochnatia polymorpha (Less.) } \\
\text { Cabrera }\end{array}$ & 0.76 & 1.06 & 0.362 & 1.732 \\
\hline 23 & Guapira opposita (Vell.) Reitz & 0.35 & 0.193 & 0.542 & 0.655 \\
\hline 24 & Guare amacrophylla Vahl & 0.79 & 0.0474 & 0.542 & 0.364 \\
\hline 25 & Guatteria australis A.St.-Hil & 0.59 & 0.0753 & 1.085 & 0.689 \\
\hline 26 & 1 Indet & 0.49 & 0.09828 & 0.181 & 0.209 \\
\hline 27 & 2 Indet & 0.51 & 0.08132 & 0.181 & 0.266 \\
\hline 28 & 3 Indet & 0.52 & 0.02326 & 0.181 & 0.131 \\
\hline 29 & 4 Indet & 0.48 & 0.2469 & 0.181 & 0.485 \\
\hline 30 & 5 Indet & 0.5 & 0.103 & 0.181 & 0.233 \\
\hline 31 & Jacaranda puberula Cham & 0.58 & 0.0871 & 0.362 & 0.198 \\
\hline 32 & Endlicheria sp. & 0.63 & 0.0612 & 0.362 & 0.278 \\
\hline 33 & Matayba intermedia Radlk & 0.61 & 2.4 & 0.723 & 2.426 \\
\hline 34 & Maytenussp. & 0.79 & 0.128 & 0.181 & 0.273 \\
\hline 35 & $\begin{array}{l}\text { Miconia cinnamomifolia (DC.) } \\
\text { Naudin }\end{array}$ & 0.57 & 0.448 & 4.702 & 3.427 \\
\hline 36 & Miconia cubatanensis hoehne & 0.63 & 0.627 & 1.447 & 1.593 \\
\hline
\end{tabular}


Estimation of the Carbon Biomass Stored in the Forest Ecosystem of the Billings Reservoir-SP

\begin{tabular}{|c|c|c|c|c|c|}
\hline 37 & Miconia fasciculata Gardner & 0.63 & 0.286 & 3.436 & 2.391 \\
\hline 38 & Miconiasp. & 0.63 & 0.0706 & 0.181 & 0.214 \\
\hline 39 & Dead & 0.5 & 1.12 & 9.765 & 8.322 \\
\hline 40 & Myrcia multiflora (Lam.) DC. & 0.60 & 0.0176 & 0.181 & 0.117 \\
\hline 41 & Myrciasp. & 0.60 & 0.0734 & 0.181 & 0.22 \\
\hline 42 & Myrcia sp2. & 0.60 & 0.0118 & 0.181 & 0.111 \\
\hline 43 & Myrciasplendens (Sw). DC & 0.63 & 0.636 & 3.797 & 2.007 \\
\hline 44 & $\begin{array}{c}\text { Myrsine aff. Balansae Mez } \\
\text { Otegui }\end{array}$ & 0.57 & 0.497 & 3.797 & 2.795 \\
\hline 45 & $\begin{array}{c}\text { Myrsine coriacea }(\mathrm{Sw}) \text {. R.Br. Ex } \\
\text { Roem. ESchult }\end{array}$ & 0.57 & 0.208 & 1.085 & 0.935 \\
\hline 46 & Myrsine gardneriana A.DC. & 0.57 & 0.113 & 0.362 & 0.361 \\
\hline 47 & Nectandra grandiflora Nees & 0.61 & 0.0701 & 0.542 & 0.411 \\
\hline 48 & Nectandrasp. & 0.66 & 0.0587 & 0.362 & 0.29 \\
\hline 49 & Nectandrasp2. & 0.66 & 0.0232 & 0.181 & 0.131 \\
\hline 50 & $\begin{array}{c}\text { Ocotea aff. nitida(Meisn.) } \\
\text { Rohwer }\end{array}$ & 0.47 & 0.0243 & 0.181 & 0.126 \\
\hline 51 & Ocotea odorifera (Vell.) Rohwer & 0.51 & 0.0503 & 0.542 & 0.36 \\
\hline 52 & $\begin{array}{c}\text { Pera glabrata (Schott) Poepp. } \\
\text { Ex Baill. }\end{array}$ & 0.63 & 0.0223 & 0.362 & 0.222 \\
\hline 53 & Pinus sp. & 0.40 & 3.7 & 0.904 & 4.188 \\
\hline 54 & $\begin{array}{c}\text { Piptocarpha axillaris (Less.) } \\
\text { Baker }\end{array}$ & 0.62 & 0.547 & 1.085 & 1.307 \\
\hline 55 & Piptocarpha sp. & 0.62 & 0.0291 & 0.181 & 0.134 \\
\hline 56 & Psidium cattleianum sabine & 1.12 & 0.195 & 1.447 & 1.06 \\
\hline 57 & PSidium $\mathrm{sp}$ & 0.96 & 0.09 & 1.808 & 1.142 \\
\hline 58 & Psychotria sp. & 0.53 & 0.00703 & 0.181 & 0.106 \\
\hline 59 & Psychotria suterella Mull. Arg. & 0.53 & 0.00432 & 0.181 & 0.108 \\
\hline 60 & PSychotria vellosiana Benth. & 0.38 & 0.0272 & 0.362 & 0.24 \\
\hline 61 & $\begin{array}{c}\text { Sapium glandulosum (L.) } \\
\text { Morong }\end{array}$ & 0.40 & 0.792 & 0.723 & 0.449 \\
\hline 62 & Schinus terebinthifolia Raddi & 0.93 & 1.48 & 3.436 & 3.995 \\
\hline 63 & $\begin{array}{l}\text { Styrax lancifolius Klotzsch ex } \\
\text { Seub }\end{array}$ & 0.59 & 0.0765 & 0.181 & 0.225 \\
\hline 65 & $\begin{array}{c}\text { Tibouchina mutabilis (Vell.) } \\
\text { Cogn. }\end{array}$ & 0.66 & 9.28 & 21.338 & 25.089 \\
\hline 66 & Toulicia laevigata radlk & 0.90 & 0.422 & 0.723 & 0.434 \\
\hline 67 & Trema micrantha (L.) Blume & 0.40 & 0.173 & 0.181 & 0.273 \\
\hline 68 & Zanthoxylum fagara (L.) Sarg & 0.75 & 0.544 & 0.362 & 0.868 \\
\hline \multirow[t]{2}{*}{69} & Zanthoxylum rhoifolium Lam. & 0.54 & 0.01303 & 0.181 & 0.113 \\
\hline & Total & 40.64 & 36.99531 & & \\
\hline
\end{tabular}

Source: by the author himself.

The quantification of biomass of wood (B) resulted in estimates of 113.73.ha ${ }^{-1}$, which corresponded to $56.87 \mathrm{tC}_{\mathrm{ha}} \mathrm{h}^{-1}$ carbon stock in the forest studied. The representativeness of forest inventory runs, it is incorrect to say that these are the estimation of biomass and carbon stored in the forest ecosystem of the Billings reservoir. 
Table 3 - Average values $(\mathrm{X})$ of the variables measured per plot; average estimates of biomass of STEM (t.ha ${ }^{-1}$ ) and carbon (t.ha $\left.{ }^{-1}\right)$ of the forest per plot and successional stage of each plot analyzed.

\begin{tabular}{|c|c|c|c|c|c|c|c|}
\hline Parcels & $G\left(m^{2}\right)$ & $\mathrm{DAP}(\mathrm{cm})$ & stature $(\mathrm{m})$ & $\begin{array}{l}\text { radius of } \\
\text { cup(m) }\end{array}$ & biomass $\left(\mathrm{m}^{3}\right)$ & C (t.ha $\left.{ }^{-1}\right)$ & phase \\
\hline 1 & 0.006094 & 8.57 & 5.56 & 2.13 & 0.02415 & 0.007217 & Page \\
\hline 3 & 0.007514 & 9 & 6.74 & 1.35 & 0.0434 & 0.012969 & Page \\
\hline 4 & 0.015629 & 11.33 & 6.4 & 1.75 & 0.08804 & 0.026308 & Average \\
\hline 5 & 0.013122 & 11.46 & 3.5 & 0.83 & 0.01528 & 0.004566 & Average \\
\hline 6 & 0.014691 & 12.46 & 7.91 & 1.75 & 0.06925 & 0.020693 & Average \\
\hline 7 & 0.0057 & 8.07 & 5.5 & 1.09 & 0.02341 & 0.006995 & Page \\
\hline 8 & 0.007127 & 8.84 & 4.89 & 1.07 & 0.02355 & 0.007037 & Page \\
\hline 9 & 0.048863 & 19.91 & 9.5 & 2.41 & 0.3183 & 0.095115 & Average \\
\hline 10 & 0.025425 & 17.19 & 10 & 2.33 & 0.1625 & 0.048558 & Average \\
\hline 11 & 0.003673 & 6.57 & 4.3 & 0.83 & 0.01234 & 0.003687 & Page \\
\hline 12 & 0.005511 & 8.11 & 4.5 & 1.65 & 0.01778 & 0.005313 & Page \\
\hline 13 & 0.009618 & 10.4 & 8.16 & 2.41 & 0.05037 & 0.015052 & Average \\
\hline 14 & 0.02677 & 18.46 & 8.5 & 2.6 & 0.1314 & 0.039265 & Average \\
\hline 15 & 0.006019 & 8.28 & 6.28 & 1.46 & 0.02774 & 0.008289 & Page \\
\hline 16 & 0.005109 & 7.76 & 5.38 & 1.66 & 0.01964 & 0.005869 & Page \\
\hline 17 & 0.003288 & 6.37 & 4.69 & 1.64 & 0.01103 & 0.003296 & Page \\
\hline 18 & 0.003858 & 6.71 & 9.15 & 2.02 & 0.03301 & 0.009864 & Page \\
\hline 19 & 0.038141 & 21.64 & 10.5 & 2.25 & 0.2297 & 0.068639 & Advanced \\
\hline 20 & 0.006118 & 8.09 & 5.87 & 1.97 & 0.029 & 0.008666 & Page \\
\hline 21 & 0.019908 & 15.6 & 9.5 & 3.33 & 0.1252 & 0.037412 & Average \\
\hline 22 & 0.041097 & 17.26 & 11.58 & 2.44 & 0.4635 & 0.138503 & Average \\
\hline 23 & 0.008535 & 9.55 & 6.4 & 1.84 & 0.03979 & 0.011890 & Page \\
\hline 24 & 0.02981 & 18.67 & 10 & 2.84 & 0.1865 & 0.055730 & Average \\
\hline 25 & 0.00473 & 7.38 & 5.17 & 1.32 & 0.01847 & 0.005519 & Page \\
\hline 26 & 0.004635 & 7.48 & 10 & 1.25 & 0.03673 & 0.010976 & Page \\
\hline 27 & 0.004652 & 7.4 & 6.92 & 1.8 & 0.02423 & 0.007240 & Page \\
\hline 28 & 0.018239 & 8.7 & 2.4 & 0 & 0.007749 & 0.002316 & Page \\
\hline 29 & 0.008387 & 9.99 & 7.43 & 1.58 & 0.04692 & 0.014021 & Page \\
\hline 30 & 0.014019 & 12.73 & 6.35 & 2.37 & 0.05124 & 0.015312 & Average \\
\hline 32 & 0.012758 & 11.94 & 11.06 & 2.75 & 0.1141 & 0.034095 & Average \\
\hline 33 & 0.004584 & 7.63 & 6.5 & 1.8 & 0.02129 & 0.006362 & Page \\
\hline 34 & 0.006828 & 8.91 & 4 & 0.76 & 0.0212 & 0.006335 & Page \\
\hline 36 & 0.055993 & 23.44 & 9.16 & 4.5 & 0.323 & 0.096519 & Advanced \\
\hline 37 & 0.022707 & 12.89 & 7.75 & 1.54 & 0.2339 & 0.069894 & Average \\
\hline 38 & 0.010021 & 10.42 & 9.75 & 2.13 & 0.0707 & 0.021127 & Average \\
\hline 40 & 0.007009 & 9 & 4.5 & 0.94 & 0.01947 & 0.005818 & Page \\
\hline 41 & 0.01204 & 8.75 & 7.25 & 1.5 & 0.03058 & 0.009138 & Page \\
\hline 42 & 0.031143 & 15.69 & 8.79 & 2.53 & 0.2595 & 0.077544 & Average \\
\hline 43 & 0.000897 & 9.44 & 5.87 & 2.26 & 0.04116 & 0.012299 & Page \\
\hline 44 & 0.007993 & 8.36 & 6.84 & 2.25 & 0.06422 & 0.019190 & Page \\
\hline
\end{tabular}


Estimation of the Carbon Biomass Stored in the Forest Ecosystem of the Billings Reservoir-SP

\begin{tabular}{cccccccc}
45 & 0.008666 & 9.16 & 6.89 & 1.99 & 0.05081 & 0.015183 & Page \\
46 & 0.003858 & 6.74 & 5.81 & 1.3 & 0.01779 & 0.005316 & Page \\
47 & 0.00391 & 6.96 & 6.38 & 1.67 & 0.01994 & 0.005958 & Page \\
48 & 0.006005 & 8.3 & 5.32 & 1.21 & 0.02234 & 0.006676 & Page \\
49 & 0.003716 & 6.61 & 3.78 & 0.86 & 0.009817 & 0.002934 & Page \\
50 & 0.053702 & 20.9 & 8.4 & 2.3 & 0.1829 & 0.054654 & Advanced \\
51 & 0.006878 & 9.03 & 6.08 & 1 & 0.02711 & 0.008101 & Page \\
60 & 0.007095 & 9.23 & 4.92 & 1.35 & 0.02449 & 0.007318 & Page \\
61 & 0.009028 & 9.07 & 7.35 & 1.9 & 0.05589 & 0.016701 & Page \\
71 & 0.009691 & 10.66 & 7.5 & 1.67 & 0.05111 & 0.015273 & Average \\
72 & 0.000322 & 10.9 & 6.78 & 1.7 & 0.0724 & 0.021635 & Average \\
77 & 0.005231 & 7.98 & 3.67 & 1.3 & 0.01243 & 0.003714 & Page \\
\hline
\end{tabular}

Source: by the author himself.

The population parameters of mature forest (Table 3), in turn, are in accordance with the submitted in Resolution $N^{0}$ 1/1994 of the Environment National Council (CONAMA), for forests in the initial stages and medium, according to SILVA et al. (2018) forests, more young people tend to use more carbon than the ripe, it is noteworthy that the forest ecosystem of the Billings reservoir presented large densities of species Tibouchina mutabilis, Cyathea cf. Corcovadensis and Euterpe edulis, these last two species do not produce secondary xylem, as already mentioned above, it is therefore important to use other methods of measurement of biomass and carbon storage in non-lignified plants, preferably non-destructive methods, once that the species Euterpe edulis is considered threatened according the state of São Paulo resolution and the species Cyathea cf. Corcovadensis is of great importance for anurofauna, being an important micro-habitat for the region.

The estimation of biomass and carbon found were similar to studies in which they obtained estimates of stem biomass without bark of Ribeiro et al. (2009), which counted 319 tree species, belonging to 177 genera and 60 families. The quantification of biomass ( $\left.B_{\text {wood }}\right)$ of the stem bark resulted in estimates of $166.67 . \mathrm{ha}^{-1}$, for a carbon stock of $83.34 \mathrm{tC}^{-\mathrm{ha}^{-1}}$, in a mature forest in Viçosa, MG according to Resolution No 29/1994 of the Environment National Council (CONAMA).

For a volumetric study on a fragment of Atlantic forest in the municipality of

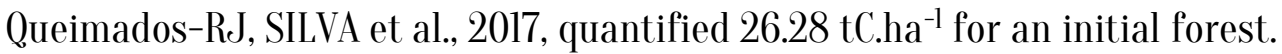

For studies performed in the Amazon Biome we have: SANTOS et al. (2018), in a study in mature forest in central Amazonia, acquired estimates of biomass $\left(\mathrm{B}_{\text {wood }}\right)$ of the bole wood with bark ranging between 299.60 and 29.46. $\mathrm{tC}^{-h a^{-1}}$, with a mean of $327.8 \pm 41.9$. tC.ha ${ }^{-1}$. SALDARRIAGA et al. (1988), in a study on ecological succession in the Amazon region, found 
wood biomass $\left(\mathrm{B}_{\text {wood }}\right)$ of the stem in four stands of mature forests ranging between 107 and 145. tC.ha-1.

In general it is noticeable that the results found for estimates of wood biomass (B) and carbon stored above ground in the Amazon Biome, provided higher values for this study, as well as for the study by RIBEIR0 et al. (2009), both in the Atlantic Forest biome, but in general the great abundance and frequency of species Cyathe acf. Corcovadensis and Euterpe edulis, which do not have secondary xylem may have contributed negatively to the values of biomass and carbon storage found in this study, suggesting that the values mentioned, are still higher than those described here, however the forest ecosystem of the Billings reservoir has proven to be extremely helpful in the carbon sequestration and storage, benefiting the society and the environment.

For carbon credits to be credible, three technical tasks must be fulfilled: biomass estimation of the forest ecosystem, management of large amounts of spatial data and assessment of forest degradation (HAJEK et al., 2011). The Estimation of carbon stock in the forest ecosystem of the Billings reservoir has met all these criteria can be used as a reference for the establishment of projects of restoration/reforestation projects under the sustainable development mechanism, agreed upon in the Kyoto Protocol, and generate the so-called carbon credits.

The estimate of the carbon stock can be used as a reference for the establishment of projects of restoration/reforestation projects under the sustainable development mechanism, agreed upon in the Kyoto Protocol, and generate the so-called carbon credits. As the Atlantic Forest is a hotspot of biodiversity, many are the actions of forest restoration carried out in its ecosystems, therefore a biome of priority to conservation and environmental preservation, the recovery of degraded areas becomes relevant to have the proper generation of environmental services, the fragment in question must be the focus of actions that maximize the succession and the conservation of biodiversity, which could be liable for the establishment of carbon projects.

\section{CONCLUSÃO}

Considering the importance of the Billings reservoir for the state of São Paulo and the need for the preservation of its ecosystem, this study estimated the biomass $\left(B_{\text {wood }}\right)$ of 113.73.ha $\mathrm{h}^{-1} \mathrm{~m}^{3}$ through the installation of 54 plots ( $\mathrm{U}$ A quadratic) of $36 \mathrm{~m}^{2}$ arranged 
systematically in a forest fragment of $48.010 .91 \mathrm{~m}^{2}$ covering an area of $1944 \mathrm{~m}^{2}$, which

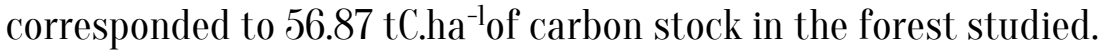

Carbon stock estimation can be used as a reference for the establishment of degraded area recovery projects under the sustainable development mechanism established in the Kyoto Protocol and to generate so-called carbon credits. The importance of this is highlighted for the Atlantic Forest, due to the large number of degraded areas that this biome possesses, which could be establishment of carbon projects.

\section{BIBLIOGRAPHICAL REFERENCES}

ABNT - ASSOCIAÇÃO BRASILEIRA DE NORMAS TÉCNICAS. NBR 11941-02 - Determinação da densidade básica em madeira. Rio de Janeiro, 2003. 6p.

ARROMBA, A.L ; LEONEL, C.; SANTIAG0, C. de M.; MAZZEI, K.; BUCCI, L. A.; NALON, M.A.; BARROS, M.I.A. Plano de Manejo do Parque Estadual Alberto Löfgren. 1. ed. São Paulo, SP: Editado pelo Instituto Florestal, 2012. v. 01. 710p .

BRASIL. Conselho Nacional do Meio Ambiente. Resolução CONAMA nº 01, de 31 de janeiro de 1994. Regulamenta o art. $6^{0}$ do Decreto $\mathrm{n}^{\mathbf{0}}$ 750, de 10 de fev. de 1993 para o Estado de São Paulo. Disponível em: 〈http://www.mma.gov.br/port/conama/res/res94/res0194.html〉. Acess in: 16 set. 2018.

BERGALlO, H. G.; BERGALl0, A. C.; ROCHA, H. B ; ROCHA, C. F. D. . Invasion by Artocarpus heterophyllus (Moraceae) in an island in the Atlantic Forest Biome, Brazil: distribution at the landscape level, density and need for control. Journal of Coastal Conservation , v. 20, p. 1-8, 2016.

BROWN, S.; GILLESPIE, A. J. R.; LUG0, A. E. Biomass estimation methods for tropical forests with applications to forest inventory data.Forest Science, vol.35, no.4, p.881-902, 1989.

DATABASE OF BRAZILIAN WOODS. 2014. Available in: <http://www.ibama.gov.br/lpf/ wood/foreword.htm>. Access in: 03 set. 2018.

FUNDAÇÃO SOS MATA ATLÂNTICA; INPE. Atlas of forest remnants of the Mata Atlântica period 2015; final report. São Paulo: The SOS. 2015.

FUNDAÇÃO CENTRO TECNOLÓGICO DE MINAS GERAIS - CETEC. Determination of Volumetric equations applicable to the sustainable management of native forests in the state of Minas Gerais, and other regions of the country. Belo Horizonte: 1995. 295p.

HUSCH, B; MILLER, C.L.; BEERS, Forest mensuration. 3. ed. New York: J. Willey GSounds, 1982. 397p

IBAMA. 2016. Flora. Available in: <www.ibama.gov.br/flora/home.htm>. Access in: 03 Jan. 2018.

INSTITUTO NACIONAL DE PESQUISAS ESPACIAIS (INPE). Sistema de Processamento de Informações Georeferenciadas. Coordenação Geral de Observação da Terra. Desenvolvido pela Divisão de Processamento de Imagens do Instituto Nacional de Pesquisas Espaciais, 2018. Disponível em: <http://www.dpi.inpe.br/spring/portugues/tutorial/introducao_sen.html〉. Access in: 03 Dec. 2018.

HENRY, M., PICARD, N., TROTTA, C., MANLAY, R.J., VALENTINI, R., BERNOUX, M. \& SAINT-ANDRÉ, L. 2011. Estimating tree biomass of sub-Saharan African forests: a review of available allometric equations. Silva Fennica 45(3B): 477569.

HAJEK, F.; VENTRESCA M. J.; SCRIVEN J.; CASTR0 A. Regime-building for REDD+: Evidence from a cluster of local initiatives in south-eastern Peru. Environmental Science \& Policy, v.14, n.2, p.201-215, 2011. 
LORENZI, H. J. Brazilian trees I. 5. ed. Nova Odessa: Publisher Plantarum, 2014. v. 2. 384p.

LUCHIARI, A.; BARROSO, L. V.; SPILlER, A.B.; CARVAlHO, L. S. DE; FERREIRA, T. A. Uso da Terra. In: FURLAN, S. A. Diagnóstico Físico e socioambiental do Parque Riacho Grande no município de São Bernardo do Campo. São Paulo, 2012. P. 279-319.

MMA. 2016. Biomes- Mata Atlântica.Availablein:<http://www.mma.gov.br/biomas/mata-atlantica>. Access in: 03 set. 2018.

RIBEIR0, S. C.; MAPELI, A. G.; SOARES, C. P. B.; MARTINS, S. V.; SOUZA, A. L.; NARDELLI, A. M.B. .Quantification of Estimation of biomass and carbon stock in a mature forest in the municipality of Viçosa, Minas Gerais. Journal of Sedimentary Petrology (Printed), v. 33, p. 917-926, 2009.

RODRIGUES, V.A. (Org.); BUCCI, L. A. (Org.); PINHEIR0, L. Z. (Org.); SIQUEIRA, H. E. (Org.); OLIVEIRA, P. J. D. (Org.). Biomas Brasileiros: conservação da biodiversidade, solo, floresta e água. 1. ed. Botucatu: Fundação de Estudos e Pesquisas Agrícolas e Florestais - FEPAF, 2017. v. único. 258p.

SANTOS, J. F; VALCARCEL, R. Avaliação Florística do Estrato Regenerante de Reflorestamentos em área Reabilitada na Mata Atlântica. Floresta e Ambiente, v. 18, p. 390-401, 2011.

SALDARRIAGA, J. G.; WEST D. C.; THARP M. L.; UHL C. Long-term chronosequence of forest succession in the upper Rio Negro of Colombia and Venezuela. Journal of Ecology, v.76, p.938-958, 1988.

SANTOS, F. G.; CAMARG0, P. B.; OLIVEIRA JUNIOR, R. C. ESTOQUE E DINÂMICA DE BIOMASSA ARBÓREA EM FLORESTA OMBRÓFILA DENSA NA FLONA TAPAJÓS: AMAZÔNIA ORIENTAL. CIÊNCIA FLORESTAL (ONLINE), v. 28, p. 1049, 2018.

SILVA, C.V.V.; SILVA, L. M. S.; TAVARES R.; SILVA, W. S. Utilização de Características Fitossociológicas e Bioindicadoras no Monitoramento Ambiental e Avaliação de Impacto Nas Bacias do Rio Guandu-rj. In: XXXI I Jornada Fluminense de Botânica, 2013.

SILVA, C.V.V.; ABREU, L. A. S.; LEAL, J. C. Uso da Volumetria na Avaliação da Concentração de Carbono da APA Guandu-Jacatirão, Queimados-RJ. In: XIV Congresso Nacional de Meio Ambiente de Poços de Caldas, 2017.

SILVA, C.V.V.; TOMAS JUNIOR, O. A.; CARVALHO, L. 0.; NOVAES, E. B. Biomassa e Estimativa de Carbono Estocado em Ecossistema Florestal da Represa Billings-SP. In: XV Congresso Nacional do Meio Ambiente, 2018.

SILVA, C.V.V.; ABREU, L. A. S.; LEA, J. C.; LOUREIR0, A.; GROETARS, A. Inventário Florístico da APA Guandu-Jacatirão o uso da Resolução CONAMA N 04, de Maio de 1994 - RJ, para Análise de Parâmetros da Qualidade Ambiental. In: XIV Congresso Nacional do Meio Ambiente, 2017.

TAVARES R.; SILVA, C.V.V.; FRANCISC0, C. F. Níveis de Ocorrência de Incêndios e Queimadas em Vegetação no Município de Itaguaí - RJ. In: IX Congresso Nacional do Meio Ambiente, 2012.

TORRES, C. M. M. E.; JACOVINE L. A. G.; SOARES C. P. B.; NETO S. N. 0.; SANTOS R. D.; NETO F. C. Quantificação de Biomassa e Estocagem de Carbono em uma Floresta Estacional Semidecidual, no Parque Tecnológico de Viçosa, MG. Revista Árvore. Viçosa, v. 37, n.4, 2013. 